\title{
Systematics of South African forest-endemic dung beetles: new genera and species of small Canthonini (Scarabaeidae: Scarabaeinae)
}

\author{
C.M. Deschodt* \& C.H. Scholtz \\ Department of Zoology and Entomology, University of Pretoria, Pretoria, 0002 South Africa
}

\begin{abstract}
Study of very small dung beetles, less than $5 \mathrm{~mm}$ long, belonging to the tribe Canthonini from Afrotemperate forests in South Africa revealed four new genera, three monotypic and one with two new species, and one new species of Peckolus Scholtz \& Howden. We describe the new taxa here. They are: Aliuscanthoniola similaris gen et sp. n., Dwesasilvasedis medinae gen et sp. n., Parvuhowdenius harrisoni gen et sp. n., Nebulasilvius gen. n. with new species Nebulasilvius insularis sp. n. and N. johani sp. n., and Peckolus poenskopius sp. n. We provide an updated key to all the African genera in the tribe Canthonini and keys to the species in the genera Nebulasilvius and Peckolus.
\end{abstract}

Key words: dung beetles, Canthonini, new genera, new species, key.

\section{INTRODUCTION}

Isolated forest fragments serve as refugia for forest-dependent species when these previously extensive forests are severely reduced in size (Haffer 1969). Various factors, including the northward drift and uplift of the African continent, caused progressive aridification of the continent from the mid-Tertiary. This eventually resulted in severe fragmentation of the South African forests, most recently from around $18000 \mathrm{BP}$ (Eeley et al. 1999), but these have been expanding since about 8000-7000 years BP (Martin 1968; Meadows \& Linder 1993). Currently, the indigenous forests of South Africa are still extremely fragmented and cover less than $0.3 \%$ of South Africa (Low \& Rebelo 1996). Cowling (1983) suggests that the forests, although phytogeographically very complex and transitional, are the result of recent re-colonization of forests from further north and the expansion of relict stands that were hidden in protected areas. These isolation and re-expansion cycles of habitat can lead to rapid differentiation especially in flightless insect species over relatively short time spans (Haffer 1969).

Von Maltitz et al. (2003) and Mucina \& Rutherford (2006) identified seven distinct groups of forests in southern Africa: southern afrotemperate, northern afrotemperate, northern mistbelt, southern mistbelt, scarp forest, northern coastal and southern coastal group. This classification is based on mathematical methods using floristic data combined to a lesser extent with faunal data and site characteristics.

*To whom correspondence should be addressed:

E-mail: cdeschodt@zoology.up.ac.za
Most of these forest fragments are very small and occur in continuous patches of less than $1 \mathrm{~km}^{2}$ (Mucina \& Rutherford 2006). They are located from the Cape peninsula eastwards following the coastline and adjacent highland interior to KwaZulu-Natal. From here their distribution extends northwards and more inland along the Drakensberg range all the way to the Soutpansberg and Blouberg. The high endemicity of the fauna of these regions has been the subject of several studies over the past 60 years (Lawrence 1953; Stuckenberg 1962; Griswold 1991) but of interest to us is that each of the fragment types has a range of small, flightless endemic scarabaeoid beetles belonging to putatively relict taxa that have been the focus of recent taxonomic studies (Medina \& Scholtz 2005; van der Merwe \& Scholtz 2005). However, most of these endemic taxa belong to the basal Gondwanan dung beetle tribe Canthonini, which is the subject of this study.

Canthonini, putatively the group basal to many other ball-rolling dung beetle taxa (but see Philips et al. (2004) for discussion on the evolution of this and other groups), appears to be represented in Africa by relicts of a once more widespread temperate fauna. Increasing aridity over the continent and possible competition with more ecologically successful rollers in the 'younger' tribes of the Scarabaeini, Gymnopleurini and Sisyphini in the surrounding savannas may have restricted the surviving taxa further. Canthonini in Africa are characterized by a high number of monotypic genera, or ones with small numbers of species 
which are almost exclusively restricted to localized areas of mainly Afrotemperate forest patches. This 'refugium' scenario is widely believed to have lead to the biotic patterns observed within these forests (see Griswold (1991) for discussion of other animal and plant groups that show these patterns). Although we have yet to study relationships among canthonine genera and between species in the genera, there is an apparent pattern of sistergroup disjunctions between close forest patches.

The African Canthonini have been fairly well studied over the past 20 years. Scholtz \& Howden $(1987 a, b)$ and Howden \& Scholtz (1987) revised the genera and subsequently they (Howden \& Scholtz 1988) described a second species of Peckolus Scholtz \& Howden. Davis et al. (1999) described a new monotypic genus, Canthodimorpha, and a new species in the genus Gyronotus Lansberge. Josso \& Prévost (2001) added a new species to Anachalcos Hope. Frolov \& Scholtz (2003) described a new genus, Dicranocara and Medina \& Scholtz (2005) revised the species of Epirinus Reiche, and added six new species to the Canthonini. Frolov (2005) added a new species to Namakwanus. Deschodt et al. (2007) added two species to Dicranocara Frolov \& Scholtz and one to Namakwanus Scholtz \& Howden. Thus the tribe currently consists of 21 genera and 92 described species in Africa.

The Canthonini is taxonomically a very diverse group and it is even suspected that different ancestors may have given rise to the species currently placed in the tribe (Scholtz \& Howden 1987a; Frolov \& Scholtz 2003; Philips et al. 2004). However, the new genera are similar to known genera currently placed in the Canthonini and are therefore also grouped in the Canthonini. All of the new taxa are less than $5 \mathrm{~mm}$ long, and most are less than $3 \mathrm{~mm}$, making them amongst the smallest dung beetles in the world. Although they belong to a group ecologically defined as 'ball-rollers' it is extremely unlikely, in view of their size, that these groups behave in this fashion. The new taxa described are Aliuscanthoniola similaris gen. n., sp. n., Parvuhowdenius harrisoni gen. n., sp. n., Nebulasilvius insularis gen. n., sp. n., N. johani gen. n., sp. n., Dwesasilvasedis medinae gen. n., sp. n., and Peckolus poenskopius sp. n. All the new taxa described in this paper are flightless. Distribution maps and figures of the habitus for all the new species are provided.

Since 1999 four new African canthonine genera have been described which, necessitated that Scholtz \& Howden's (1987a) key to the African canthonine genera be updated.

Institutions in which type material is deposited are as follows: BMNH: The Natural History Museum, London, England; NCSA: National Collection of Insects, Pretoria, South Africa; SAMC: South African Museum, Cape Town, South Africa; TMSA: Transvaal Museum, Pretoria, South Africa; UPSA: University of Pretoria Scarab Collection, Pretoria, South Africa. Spelling on labels is reported verbatim. Authors' comments are in square brackets.

\section{Key to the genera of African Canthonini} (Modified from Scholtz \& Howden 1987a)

1 Fore tarsus absent ................

- Fore tarsus present ............. 5

2(1) Metasternum between middle coxae approximately as wide as length of coxa; middle and hind tibiae with longitudinal rows of numerous setae; tibial edges not knobbed or irregularly serrate ........ 3

- Metasternum between middle coxae distinctly narrower than length of coxa; middle and hind tibiae with irregularly spaced rows of setae; tibial edges knobbed or serrate........... Circellium Latreille

3(2) Metathoracic wings rudimentary or absent..................... 4 Metathoracic wings well developed ................ Anachalcos Hope

4(3) Penultimate sternite on abdomen arcuate .. Canthodimorpha Davis Scholtz \& Harrison Penultimate sternite on abdomen on either side of mid-line sinuate .............. Gyronotus Lansberge

5(1) Anterior tibia with two teeth on outer margin ......................6 6

- Anterior tibia with three teeth on outer margin ...................... 7

6(5) Clypeus in dorsal view with two short lateral teeth, if more than two, then smaller tooth is medial . Byrrhidium Harold Clypeus in dorsal view with two long horns ....... Dicranocara Frolov \& Scholtz

7(5) Pygidium with fovea on each side basally or with central concavity............8 8 Pygidium convex or flat, tuberculate or costate, sometimes transversely shallowly concave near basal margin, if so, lacking distinct fovea . . . . . . . . . . . . . . . 13 
8(7) Anterior margin of clypeus lacking small tooth or denticle on midline ..........9 9 Anterior margin of clypeus with small tooth or denticle on midline............ ................. Odontoloma Boheman

9(8) Metasternum anteriorly with deep fovea on each side of midline, and pronotal disk on each side near posterior angle with short, elevated carina ........ Endroedyolus Scholtz \& Howden Metasternum anteriorly without deep fovea on each side of midline, and pronotal disk with or without short elevated carina on each side near posterior angle....................... 10

10(9) Pronotal disk without short, elevated carina on each side near posterior angle ........................... 11 Pronotal disk with short elevated carina on each side near posterior angle ............... Aliuscanthoniola gen. $\mathrm{n}$.

11(10) Mesosternum wide, with more than two irregular rows of punctures ....... Outenikwanus Scholtz \& Howden

- Mesosternum very narrow, with at most one irregular row of punctures ...... 12

12(11) Sternacostal suture angulate at apex, (Fig.12B) ......... Parvuhowdenius gen. $\mathrm{n}$. Sternacostal suture rounded at apex (Fig. 12C,D). ........ Nebulasilvius gen. $n$.

13(7) Elytron at or immediately laterad of seventh stria carinate, area below carina slanted inwardly..................... 14

- Elytron at or immediately laterad of seventh stria, not or only slightly carinate, area rounded with edge turned inward at or below eighth stria ........... 17

14(13) Hind tarsus with basal two segments almost subequal in length ..........15 Hind tarsus with basal segments approximately twice as long as second segment .............. Madaphacosoma Paulian

15(14) Apex of fore tibia deeply notched above tarsal intersection; small species, length $3.5 \mathrm{~mm}$ or less ................. 16

- Apex of fore tibia almost truncate not deeply indented or notched; mediumsized species, $4 \mathrm{~mm}$ or more ............... Aphengoecus Péringuey

16(15) Pygidium evenly convex; tarsal claws toothed............ Bohepilissus Paulian midline; tarsal claws not toothed .......... Tanzanolus Scholtz \& Howden

17(13) Tarsal claws not toothed. ........... 18

- Tarsal claws toothed. Janssensantus Paulian

18(17) Apex of hind tibia angled, one side extending distinctly beyond tarsal insertion ... 19 Apex of hind tibia almost truncate, only slightly angled (i.e. one side not obviously extended) $\ldots \ldots \ldots \ldots \ldots \ldots \ldots \ldots 20$

19(18) Tarsal claws present; dorsum very dark brown or black....... Pycnopanelus Arrow

- Tarsal claws absent; dorsum with head black, pronotum reddish brown, elytra tan.......... Hammondantus Cambefort

20(18) Metasternum between middle coxae narrow, rounded anteriorly .........21

- Metasternum between middle coxae widened near anterior end, margin frequently nearly straight $\ldots \ldots \ldots \ldots 22$

21(20) Dorsal setae absent or minute; fore tibial teeth minute; metathoracic wings present ..................... Panelus Lewis

- Dorsal setae conspicuous, erect, recurved; fore tibial size moderate in size; metathoracic wings absent ........... Peckolus Scholtz \& Howden

22(20) Two clypeal teeth moderately to strongly developed, small median tooth on lower margin of clypeus; dorsum strongly convex; apical half of pygidium ventrally curved anteriorly ........ Namakwanus Scholtz \& Howden Two clypeal teeth feebly to moderately developed, no median tooth on lower margin of clypeus; dorsum not strongly convex; pygidium almost vertical downward ....................... 23

23(22) Outer margin of hind tibia curving inward, if elytra not glabrous, then setose ................... Epirinus Reiche

- Outer margin of hind tibia straight, elytra tomentose ... Dwesasilvasedis gen. $\mathrm{n}$.

\section{Description of new genera}

Genus Dwesasilvasedis gen. n., Figs 1, 2, 13 Type-species: Dwesasilvasedis medinae sp. $\mathrm{n}$.

Length. $4.2-4.8 \mathrm{~mm}$.

Head. Clypeus bidentate, with denticles rounded; slightly convex with numerous small punctures; punctures close together; ocular canthus almost dividing eye in two, dorsal part of eye very small; 


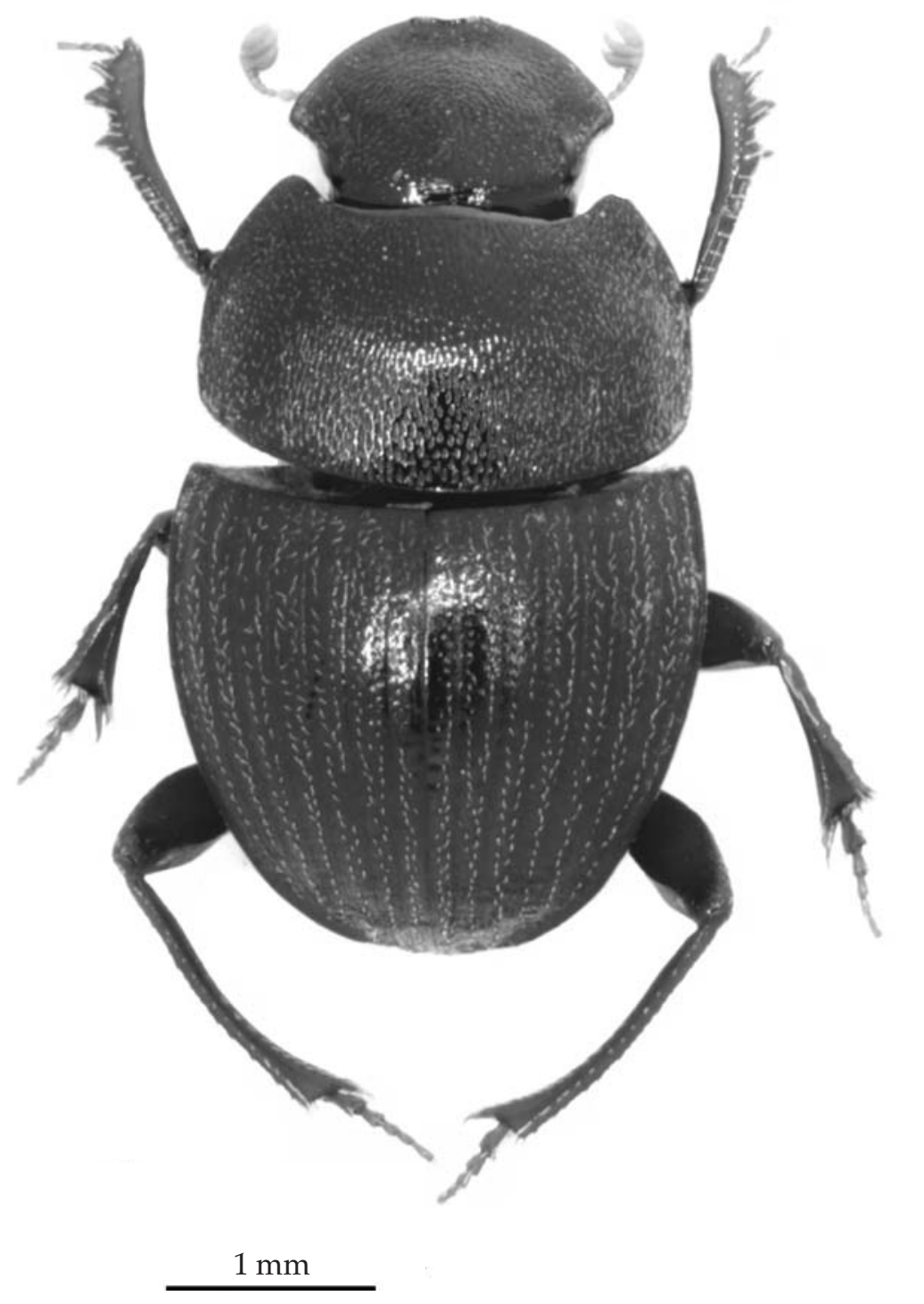

Fig. 1. Dwesasilvasedis medinae habitus.

short setae from under lateral margins of clypeus visible from above.

Pronotum. Punctation variable in size, oviform; setae pale, very short and fine, curved backwards; surface next to punctures smooth, evenly convex, with a glossy purple sheen; lateral margin rounded.

Elytra. Convex; humeral umbone absent; all punctures with short, recurved setae; striae clearly visible with small punctures; interstriae with one to four rows of setae, all posteriorly reduced to a single row; punctural setae much longer than strial setae; elytra fused; hind wings absent.

Sternum. Mesosternum and metasternum fused with suture angulate, lateral sides of suture parallel and close to mesocoxa; area between coxa and suture very narrow and smooth; punctures on mesosternum big and shallow, closer together than one puncture diameter; setiferous punctures on metasternum somewhat ovoid; punctures shallow and smaller than on mesosternum; punctures about one puncture diameter apart but 


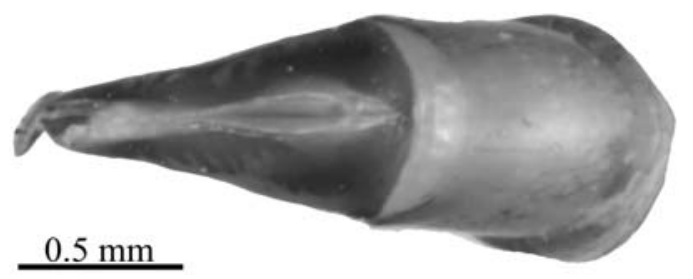

Fig. 2. Dwesasilvasedis medinae aedeagus.

getting slightly smaller and farther apart towards anterior end.

Pygidium. Triangular; all punctures with single seta; setae white and fine, but often abraded.

Fore tibia. Punctate with three long teeth, worn in some specimens; numerous bristle-like setae from same point on both sides of each tooth, one long tibial spur; single groove at outside edge of dorsal basal half; single row of bristle-like setae located in punctures in groove; basal half of outside ventral margin serrated.

Aedeagus. Asymmetrical, slender; ventrally viewed, left paramere forming a flat spoon-like structure; right paramere short and blunt.

Etymology. Dwesa $=$ the only locality were the species has been collected, Silva = Forest, from Latin, sedes $=a$ dwelling place, from Latin. The gender is feminine.

Diagnosis. This new genus is most similar to Epirinus Reiche but can be distinguished from the latter by the straight outer margin of the hind tibia and the white pilosity covering most of the body. The shape of the aedeagus of Epirinus is similar for all species while this aedeagus is more slender and longer than those in Epirinus.

Dwesasilvasedis medinae sp. n., Figs 1, 2, 13 Length. Holotype male, $4.2 \mathrm{~mm}$ long; length ranging up to $4.8 \mathrm{~mm}$ in some females. Males slightly smaller than females.

Head. Clypeus bidentate with denticles close together and slightly upturned.

Pronotum. Convex, with oviform punctures; setae short.

Elytra. Convex; striae evident, with setiferous punctures; setae very short; interstriae with setiferous punctures and longer white setae, second and third interstriae with four irregularly-spaced rows; punctures coarse and shallow.

Sternum. As for generic description. All abdominal sternites with single row of setiferous punctures except last which is wide, with irregular setiferous punctures; setae short, recurved, white.
Pygidium. Convex with irregular setiferous punctures; setae fine, long and white; area between punctures smooth.

Foretibia. As for generic description.

Aedeagus. Asymmetrical (see Fig. 2).

Material examined. Holotype: $₫$ Dwesa forest, Eastern Cape, S32.2880 E28.8323 $54 \mathrm{~m}$, 15.xi.2005 sifted forest litter, C. Deschodt (TMSA). Paratypes: 27 same data $(1 \hat{\alpha}, 4$ 우 (99 \% ethanol) UPSA, 2 ㅇ TMSA,

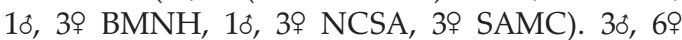
Transkei coast, Dwesa for. res., 32.17S - 28.50E, 27.2.1985; E-Y: 2174, sift. Indig. for. litt, leg. Endrödy-Younga (TMSA).

Discussion. Dwesa forest is a large fragment (c. 2000 ha) of coastal forest. It is the biggest of a series of isolated coastal forests in the area between Port St. Johns and East London in the Eastern Cape Province. Von Maltitz (2003) places it in the Transkei Coastal Scarp Forest type. Its climate is regulated by the ocean. It receives on average $1038 \mathrm{~mm}$ rain per year, has a maximum mean temperature of $20^{\circ} \mathrm{C}$ and a yearly average temperature of $18.9^{\circ} \mathrm{C}$.

Etymology. The species is named for Claudia A. Medina, who first identified this genus.

Genus Aliuscanthoniola gen. n., Figs 3, 4, 12, 13

Type-species: Aliuscanthoniola similaris sp. $\mathrm{n}$.

Males and females are similar.

Length. 2.5-2.6 mm.

Head. Punctate with punctures small and close together; clypeus bidentate, denticles small, separated by approximately two times their length; antennae golden yellow; eye not visible dorsally.

Pronotum. Strongly convex to humped; short carina on each side of disc near posterior angles; punctures small, irregular; short, recurved, golden setae stemming from punctures; punctures without setae probably due to abrasion.

Elytra. Black; long golden-brown recurved setae located in punctures; most setae abraded on top of body; ends of setae not touching elytra; striae double grooved; elytra fused; hind wings absent.

Sternum. Mesosternum and metasternum fused, suture angulate; wider posteriorly and narrowing towards anterior end of sternum; single row of punctures between anterior end of suture and sternal ridge; punctures on metasternum distinct, extending to caudal end of plate, punctures small 


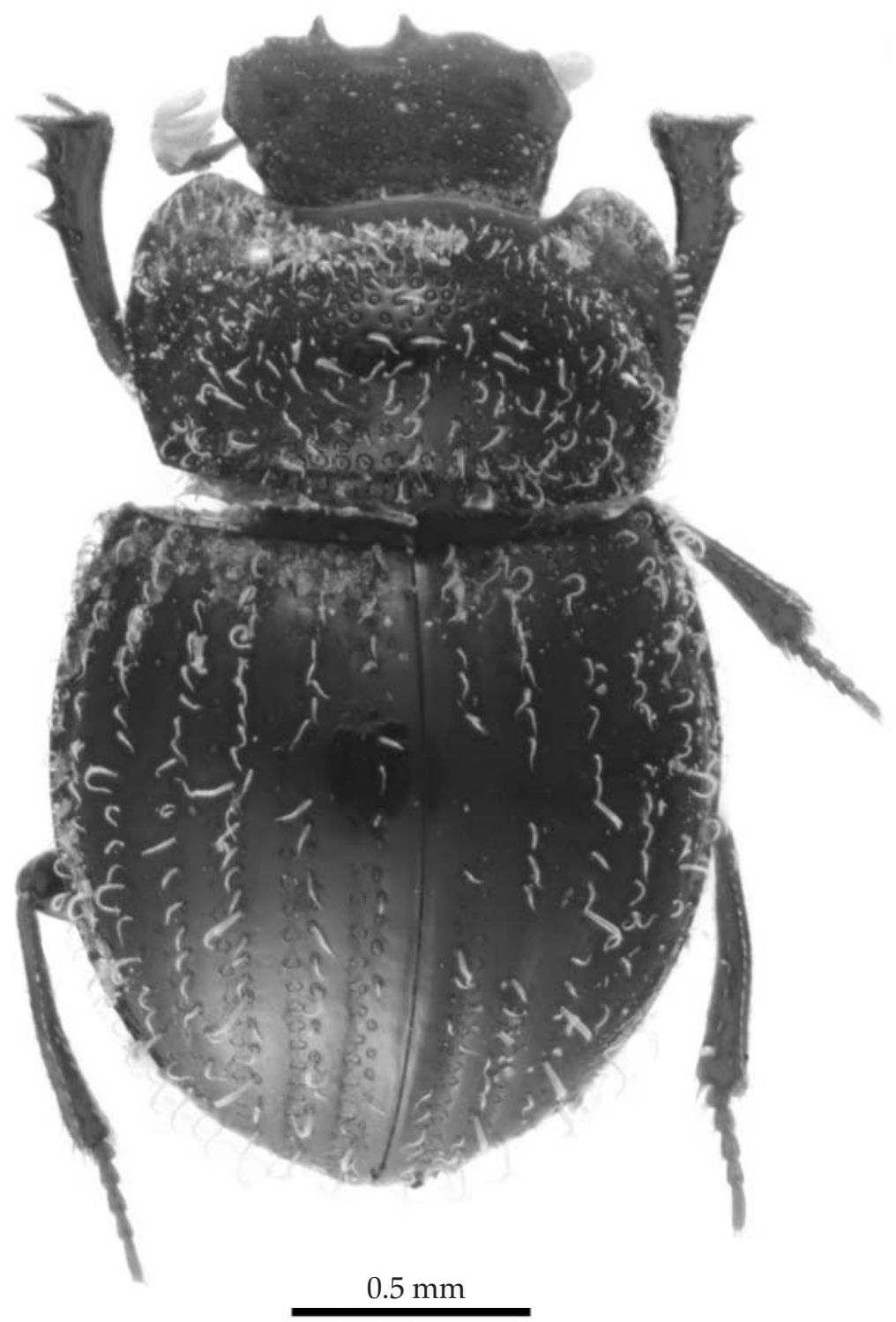

Fig. 3. Aliuscanthoniola similaris habitus.

and separated by more than one puncture diameter; slight depression between coxa and anterior angles of suture; depression punctate; punctures on mesosternum bigger than those on metasternum; all abdominal sternites with single row of punctures except last with irregular-spaced punctures.

Pygidium. Flat with shallow depression, deepest under upper side; irregularly punctate with short golden brown setae from punctures; punctures further apart than width of puncture.

Foretibia. Narrow at base, flaring from middle tooth to two times basal width.

Aedeagus. Symmetrical, with long and thin parameres.

Etymology. Aliuscanthoniola, from Latin, literally another small Canthonine. The gender is feminine.

Remarks. This genus looks superficially very similar to Outenikwanus Scholtz \& Howden and Endroedyolus Scholtz \& Howden the other small Eastern Cape forest genera but can be distinguished from them by the presence of a short, elevated carina on either side of the pronotum and 


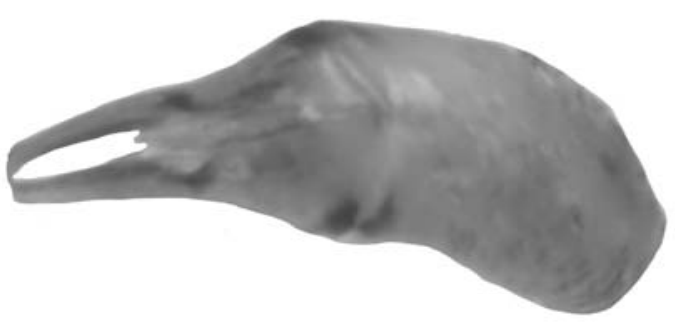

$0.5 \mathrm{~mm}$

Fig. 4. Aliuscanthoniola similaris aedeagus.

the absence of deep pits on the metasternum. Following Scholtz \& Howden (1987a), these characters warrant the establishment of a new genus.

Aliuscanthoniola similaris sp. n., Figs 3, 4, 12, 13

Length. Holotype $2.5 \mathrm{~mm}$.

Head. Clypeus bidentate, teeth separated by almost two times their length; surface punctate with punctures close together.

Pronotum. Small setiferous punctures, close together; setae golden brown, recurved.

Elytra. Striae double with punctures slightly bigger than striae are wide; interstriae with single rows of short recurved setae.

Sternum. As for generic description.

Pygidium. Shallow depression starting at upper side, gradually flattening.

Foretibia. Narrow at base and flaring from middle denticle to two times the basal width; single row of golden brown setae at dorsal outside margin; ending blunt with a spur pointing downward from middle of anterior end of tibia.

Aedeagus. Symmetrical, similar to other species in the Outenikwanus/Endroedyolus group.

Material examined. Holotype: ơ S.Afr.;Transkei, Ntsubane For. St., 31.27 S-29.44 E, 25.11.1988; E-Y:2579, forest floor litter, Leg. Endrödy-Younga (TMSA). Paratypes: 90 same data except 1.12.1988; E-Y2593 (4 TMSA, 3 UPSA, 2 NCSA), 4 우 (1 TMSA, $1 \mathrm{BMNH}, 1 \mathrm{UPSA}), 39$ same data as holotype (TMSA).

Remarks. Ntsubane forest falls in the Pondoland scarp forest type (scarp group) which is located north of Port St Johns on the southeastern coast of South Africa. It receives slightly more rain $(1162 \mathrm{~mm})$ and is marginally warmer $\left(19.3^{\circ} \mathrm{C}\right.$ yearly average) than Dwesa forest to the south.
Etymology. At first impression, this species looks very similar to most of the other species in the Endroedyolus/Outenikwanus group of genera.

Genus Parvuhowdenius gen. n., Figs 5, 6, 12, 13 Type-species: Parvuhowdenius harrisoni sp. $\mathrm{n}$.

Males similar to females.

Length. 2.5-2.7 mm.

Head. Clypeus bidentate, lateral sides scalloped; teeth small; punctures small and close together.

Pronotum. Punctures very small; setae short, recurved.

Elytra. Convex, fused; striae with a single row of recurved, sharply tapering setae; hindwings fused, flightless.

Sternum. Meso- and metasternum fused, sternacostal suture rounded anteriorly; lateral edges of suture narrowing anteriorly; arrow band of irregular punctures between presternal ridge and sternacostal suture; depression between sternacostal suture and anterior side of middle coxa obvious with few punctures; punctures on metasternum medium, extending to posterior end of plate in same pattern, separated by about one puncture diameter; punctures on mesosternum bigger than those on metasternum; very slight depression in middle of metasternum.

Pygidium. Depression shallow; smooth with few punctures.

Foretibia. Narrow but widening towards tarsus; tridentate, first tooth bigger than second and third; short, golden brown setae irregularly spaced.

Aedeagus. Symmetrical, parameres shorter than basal piece, forming scalene right-angled triangle ending bluntly.

Etymology. This genus is named in honour of Henry F. Howden of Ottawa, Canada in recognition of his massive contribution to studies on the Scarabaeoidea of the world. The gender is masculine.

Remarks. The aedeagus shape and presence of rounded sternacostal suture are unlike those found in any other related group and warrant the establishment of a separate genus. This genus can consequently be separated from the other similar genera by these characters.

Parvuhowdenius harrisoni sp. n., Figs 5, 6, 12, 13

Length. $2.5 \mathrm{~mm}$.

Head. Lateral sides of clypeus scalloped; denticles 


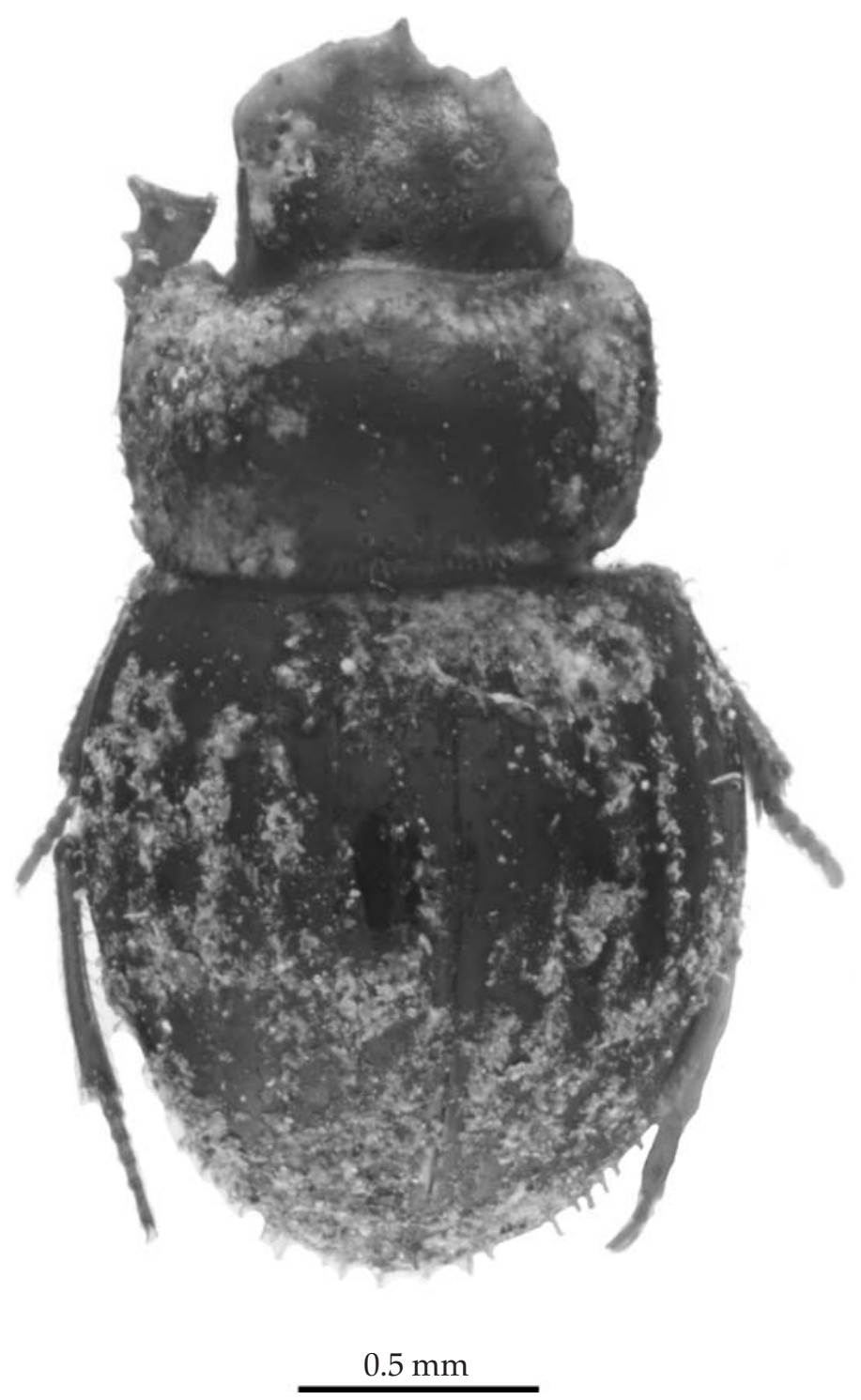

Fig. 5. Parvuhowdenius harrisoni habitus.

small and farther apart than combined length; punctures small.

Pronotum. Punctures small and separated by about one puncture diameter; setae short, recurved.

Elytra. Convex; striae with single row of setiferous punctures; setae very short, recurved, sometimes touching elytra, irregularly interrupted by long, upright setae with ends curved backwards; elytra fused; hind wings absent.

Sternum. Meso- and metasternum fused, sternacostal suture rounded anteriorly; lateral edges of suture narrowing anteriorly; narrow band of irregular punctures between presternal ridge and sternacostal suture; depression between sternacostal suture and anterior side of middle coxa obvious with few punctures; punctures on metasternum medium, extending to posterior end of plate by same pattern, separated by about one puncture diameter; punctures on mesosternum bigger than those on metasternum; very slight depression in middle of metasternum. Single row of punctures on all abdominal sternites, except last 


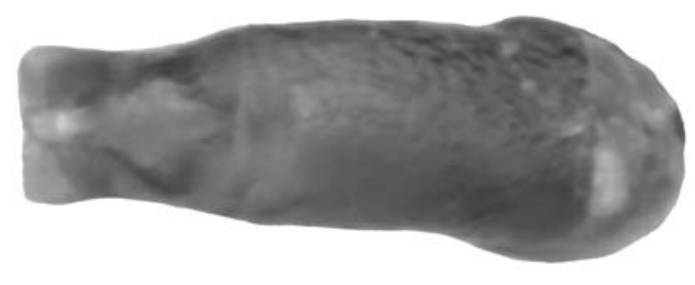

$0.5 \mathrm{~mm}$

Fig. 6. Parvuhowdenius harrisoni aedeagus.

with irregular punctuation.

Pygidium. Depression very shallow, smooth.

Foretibia. Narrow at base, widening evenly towards tarsus.

Aedeagus. Symmetrical, parameres short, sinuate and ending bluntly.

Material examined. Holotype: ơ S.Africa; Natal Middld., Karkloof For. 1300m, 29.18 S-30.13 E, 05.12.1989; E-Y:2745, Sifted forest litter, Endrödy and Klimaszew[ski]. (TMSA). Paratypes: 2 same data. (1 TMSA, 1 UPSA).

Remarks. Karkloof forest is a large (c. 1500 ha), isolated forest in the Eastern Mistbelt Forest type as defined by Von Maltitz (2003). It is 1200-1500 m above sea level with an average of $1318 \mathrm{~mm}$ of rain per annum. The average yearly temperature is $14.7^{\circ} \mathrm{C}$. Thick mists are common in spring and summer.

Etymology. This species is named for James du Guesclin Harrison in recognition of his systematic revision of Scarabaeus (Pachysoma) and the other African flightless Scarabaeini.

Genus Nebulasilvius gen n., Figs 7, 8, 12, 13

Type-species Nebulasilvius insularis sp. $\mathrm{n}$.

Males and females of the genus are similar.

Length. 2.0-2.5 mm.

Head. Clypeus bidentate; dorsal eyes very small.

Pronotum. No carina on lateral sides of pronotum.

Elytra. Fused; hindwings absent.

Sternum. Meso- and metasternum fused; at most a single row of punctures on mesosternum; no deep pits on metasternum.

Pygidium. With deep groove or shallow depression; abdominal sternites sometimes with setiferous punctures.

Fore tibia. Tridentate; fore tarsus present.

Aedeagus. Symmetrical, very similar to the aedeagi of the other species in the Outenikwanus/
Endroedyolus/Peckolus/Aliuscanthoniola group to which it is probably related.

Remarks. This genus can easily be confused with the other closely related genera. It can, however, be separated from them by not having an elevated carina on the pronotum or deep pits on the metasternum and at most having a single row of punctures on the mesosternum. The sternacostal suture is angulate.

It is restricted to the Eastern Mistbelt Forest type of Von Maltitz et al. (2003).

\section{Key to species of Nebulasilvius gen. $\mathrm{n}$.}

1 Punctures on mesosternum big and clear, separated by less than one puncture diameter (Fig. 12C) ......N. insularis sp. n.

- Punctures on mesosternum small and separated by at least one puncture diameter (Fig. 12D) ............ N. johani sp.n.

\section{New species of Nebulasilvius}

Nebulasilvius insularis sp. n., Figs 7, 8, 9, 12, 13

Length. 2.2-2.4 mm.

Head. Punctate with punctures small; distance between punctures less than one puncture width; clypeus bidentate, teeth small, just more than two times one length apart; area between and behind teeth concave; antennae golden yellow.

Pronotum. Pronotum punctate with punctures small; distance between punctures less than one puncture diameter; area between punctures smooth; pronotum with short, golden setae curved backward and downward, touching pronotum; setae originating from punctures.

Elytra. Black. Striae double, scalloped; each interval with a single row of punctures with recurved setae (often abraded) originating from punctures; elytra fused; hind wings absent.

Sternum. Meso- and metasternum fused. Wider posteriorly and narrowing towards anterior of metasternum; single row of punctures between sternacostal suture and presternal ridge; punctures on metasternum obvious and extending by same pattern all the way to posterior end of plate, punctures separated by less than one puncture diameter, absent at anterior end of plate; slight depression on mesosternum between sternacostal suture and anterior side of middle coxa; depression punctate; punctures on mesosternum slightly 


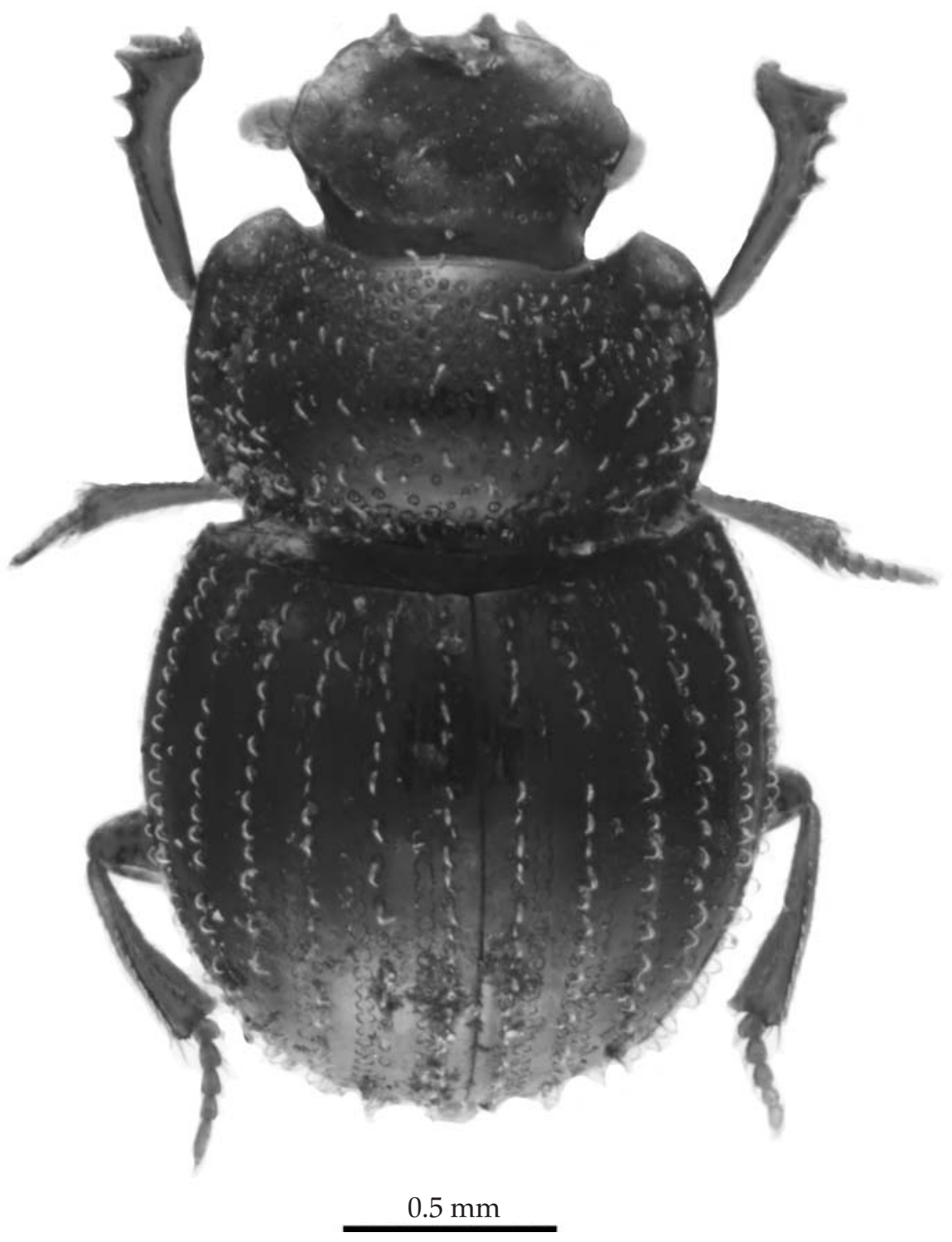

Fig. 7. Nebulasilvius insularis habitus.

bigger than on metasternum. All abdominal sternites with single row of punctures, some setiferous, except last with irregular spaced punctures. Pygidium. With setiferous punctures; deep depression in middle third of pygidium; upper ridge sloping over pygidium.

Foretibia. Very slender at base, flaring from middle denticle to two times original width. Aedeagus. Symmetrical.

Material examined. Holotype: of S.Africa; Natal Middld. Doreen Clarck Nat. R. 29.34 S-30.17 E
11.12.1989; E-Y:2750. River bank in Forest. Endrödy and Klimaszew[ski] (TMSA). Paratypes: same locality but 88 with E-Y \# 2750 (50), 119

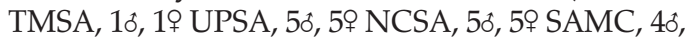

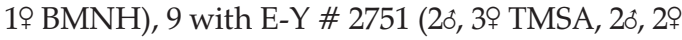
UPSA) and 7 with E-Y \# 2759 (2 $\delta, 2$ 우 TMSA, 1 1 , 2 우 UPSA).

Remarks. Doreen Clarck Reserve is a small isolated forest pocket located just north of Pietermaritzburg that probably forms part of Von Maltitz's (2003) eastern mistbelt forest type. It is 


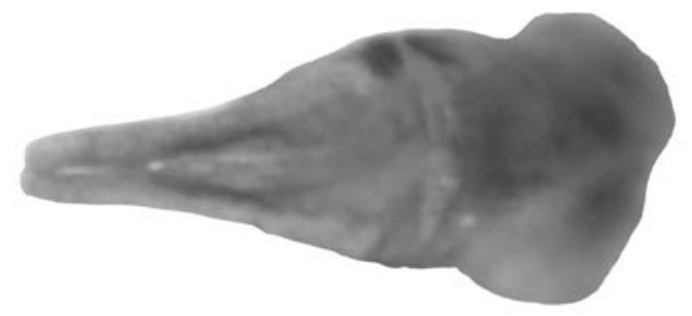

$0.5 \mathrm{~mm}$

Fig. 8. Nebulasilvius insularis aedeagus.

quite moist with about $1300 \mathrm{~mm}$ of rain annually and has an average temperature of $16.9^{\circ} \mathrm{C}$ annually. Heavy mist occurs regularly in spring and summer.

Etymology. The specific name refers to the type locality which is an indigenous island surrounded by a sea of human development.

Nebulasilvius johani sp. n., Figs 9, 12, 13 Length. $2.3 \mathrm{~mm}$.

Head. Punctures small with distance between them shorter than diameter of one puncture; clypeus bidentate with denticles small.

Pronotum. Punctate with golden, recurved punctural setae; punctures same shape and size as on head.

Elytra. Convex; double striae, scalloped; setae recurved and apex touching elytra; elytra fused; hindwings absent.

Sternum. Meso- and metasternum fused, suture almost angulate; lateral edges of sternacostal suture almost parallel; punctures on mesosternum close together, almost touching; single row of punctures between presternal ridge and suture; depression between sternacostal suture and anterior side of middle coxa very shallow, punctate; punctures on metasternum small, separated by more than one puncture diameter, extending to base of plate, anteriorly bigger but posteriorly getting smaller; faint; metasternal punctures smaller than on mesosternum. All abdominal sternites with setiferous punctures; setae very short and thin, lying backwards.

Pygidium. Flat with deep groove from middle extending towards top, ending in deep pit under basal ridge; groove about one fifth as wide as widest part of pygidium; sides steep, shallow at base.
Foretibia. Very slender at base and flaring from middle denticle to two times original width.

Aedeagus. Lost.

Material examined. Holotype: ơ S.Afr; S.Natal, Weza. Lower Stinkwood for., 30.34 S-29.43 E 17.11.1989;E-Y:2687. groundtraps 11 days. Endrödy and Klimaszew[ski]. (TMSA).

Discussion. The Weza forest complex incorporates both the Lower Stinkwood and the Bangeni forests. It is a series of reasonably close fragments of forest in the eastern mistbelt forest type. The altitude varies from $950-1200 \mathrm{~m}$ a.s.l. These forests are quite moist $(1100 \mathrm{~mm}$ and $1700 \mathrm{~mm}$ rain per annum) and heavy mists occur during spring and summer. The average yearly temperature is $13.8-15.5^{\circ} \mathrm{C}$ for both localities.

Amongst the specimens seen from the Transvaal Museum was another specimen of Nebulasilvius. (S.Afr; Natal Weza, Bangeni forest, 30.38 S-29.39 E, 21.11.1989; E-Y:2706, Sifted forest litter, Endrödy and Klimaszew[ski].) This specimen is most likely a different species but more specimens from both localities are needed before a decision can be taken on its status.

Etymology. This species is dedicated to the memory of Johan Carstens. His brave fight against cancer will always be inspirational to those who knew him.

\section{Genus Peckolus Scholtz \& Howden}

Type species. Peckolus parvus Scholtz \& Howden, by original designation.

\section{Key to the species of Peckolus Scholtz \& Howden}

1 Second and third fore tibial teeth minute, much less than half the size of the first .. 2

- Second and third fore tibial teeth small, almost half the size of the first .......... ............ P. parvus Scholtz \& Howden

2(1) Recurved setae almost half the length of straight setae. P. alpinus Howden \& Scholtz Recurved setae barely discernible ................ P. poenskopius sp. n.

Peckolus poenskopius sp. n., Figs 10, 11, 12, 13

Length. $2.0 \mathrm{~mm}$.

Head. Anterior clypeal teeth small and widely separated, distance between teeth more than two times the length of one tooth; short, straight, golden brown setae posteriorly, anteriorly probably 


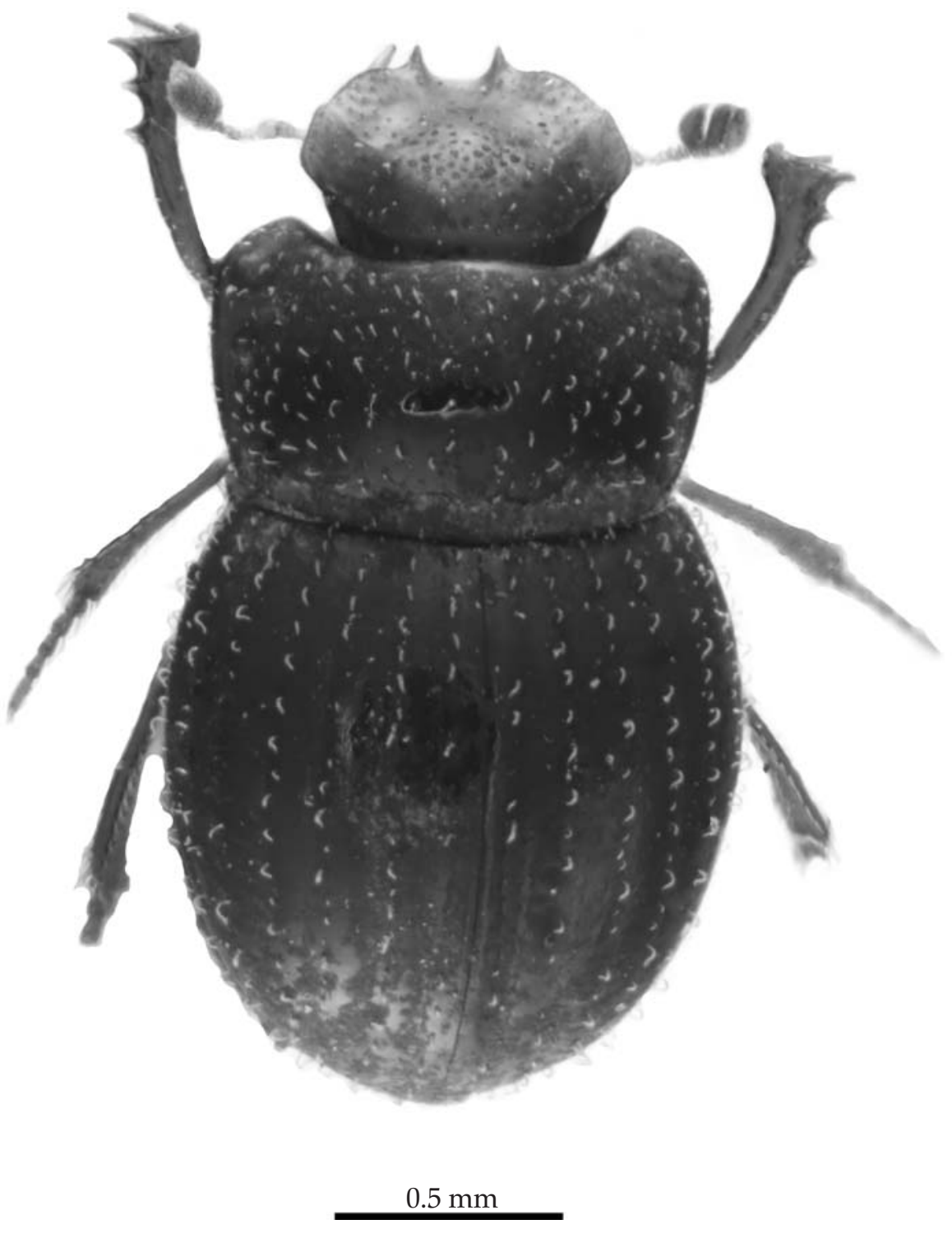

Fig. 9. Nebulasilvius johani habitus.

abraded; punctuation small, close together, less than one puncture diameter apart; ventral surface of eye small; eye not visible dorsally.

Pronotum. Setae golden brown, longer and straight in centre of disc, becoming shorter and recurved towards sides; punctures small and close together.

Elytra. Convex; evident straight, golden brown setae irregularly placed after every second or third very short, thin, recurved seta; except for single row of setiferous punctures, interstriae are smooth; elytra fused; hind wings absent.

Sternum. Mesosternum and metasternum fused, suture rounded, lateral components bending outwards; metasternum big in comparison to mesosternum; area between ridge and suture wide with numerous irregular punctures; punctures on mesosternum and metasternum same size, closer on mesosternum; metasternal punctures covering plate; depressions on mesosternum extending towards each other, almost connecting. All abdominal segments with regular very short 


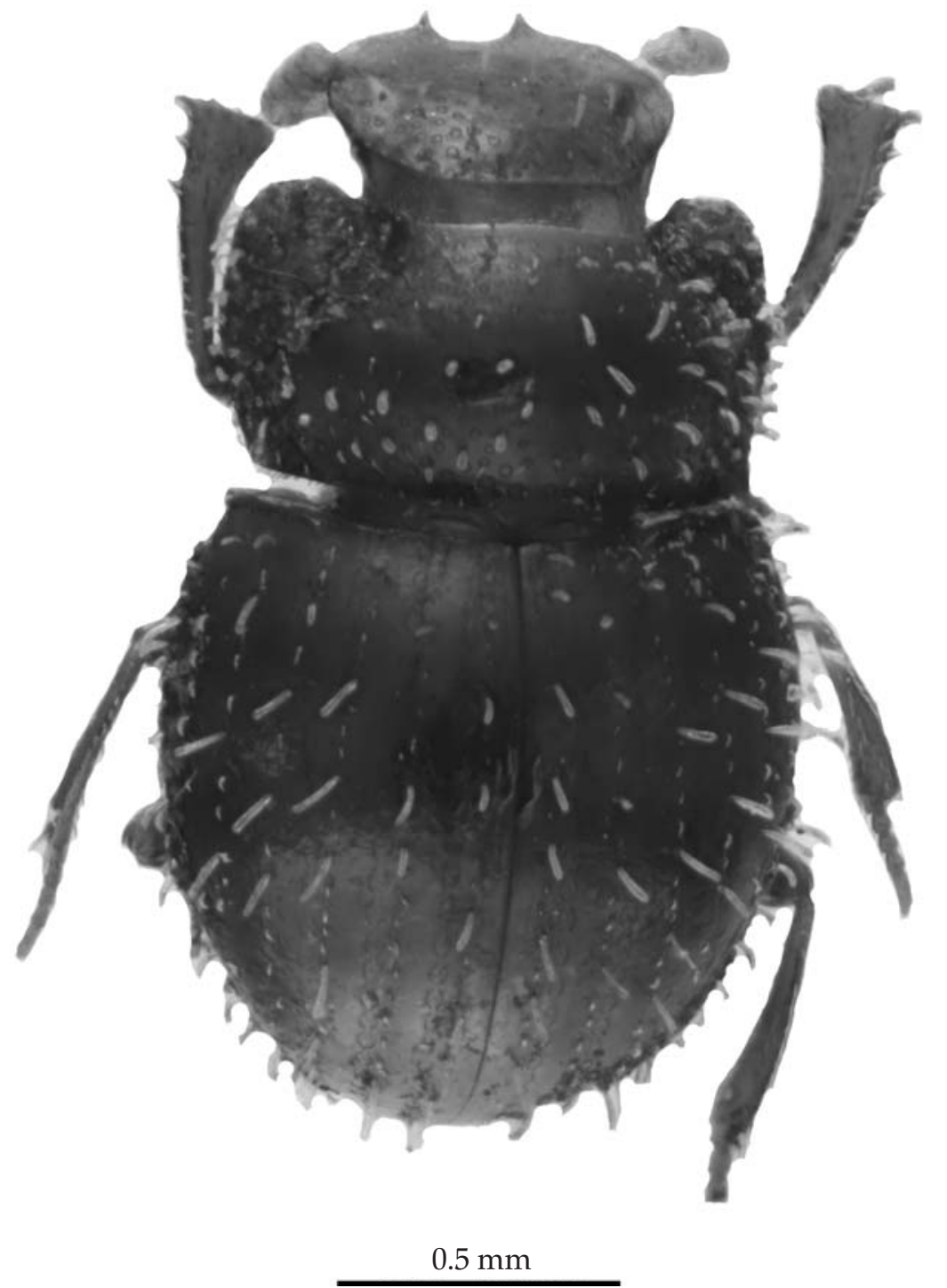

Fig. 10. Peckolus poenskopius habitus.

and thin setiferous punctures except last segment where setae are longer and thicker.

Foretibia. Slender at base, widening evenly; denticles very small.

Pygidium. Small setiferous punctures, ends of setae curving upwards; upper ridge hanging over pygidium.

Aedeagus. Symmetrical; parameres bending acutely downwards.

Diagnosis. This species is very close to P. alpinus Howden \& Scholtz, but can be separated from it by virtue of the elytral setae being thicker and longer.

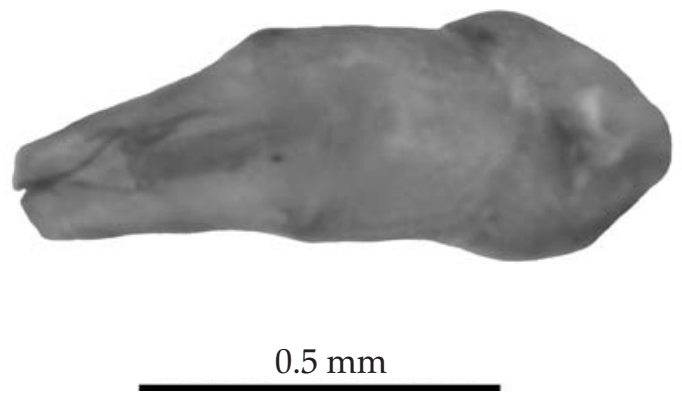

Fig. 11. Peckolus poenskopius aedeagus. 


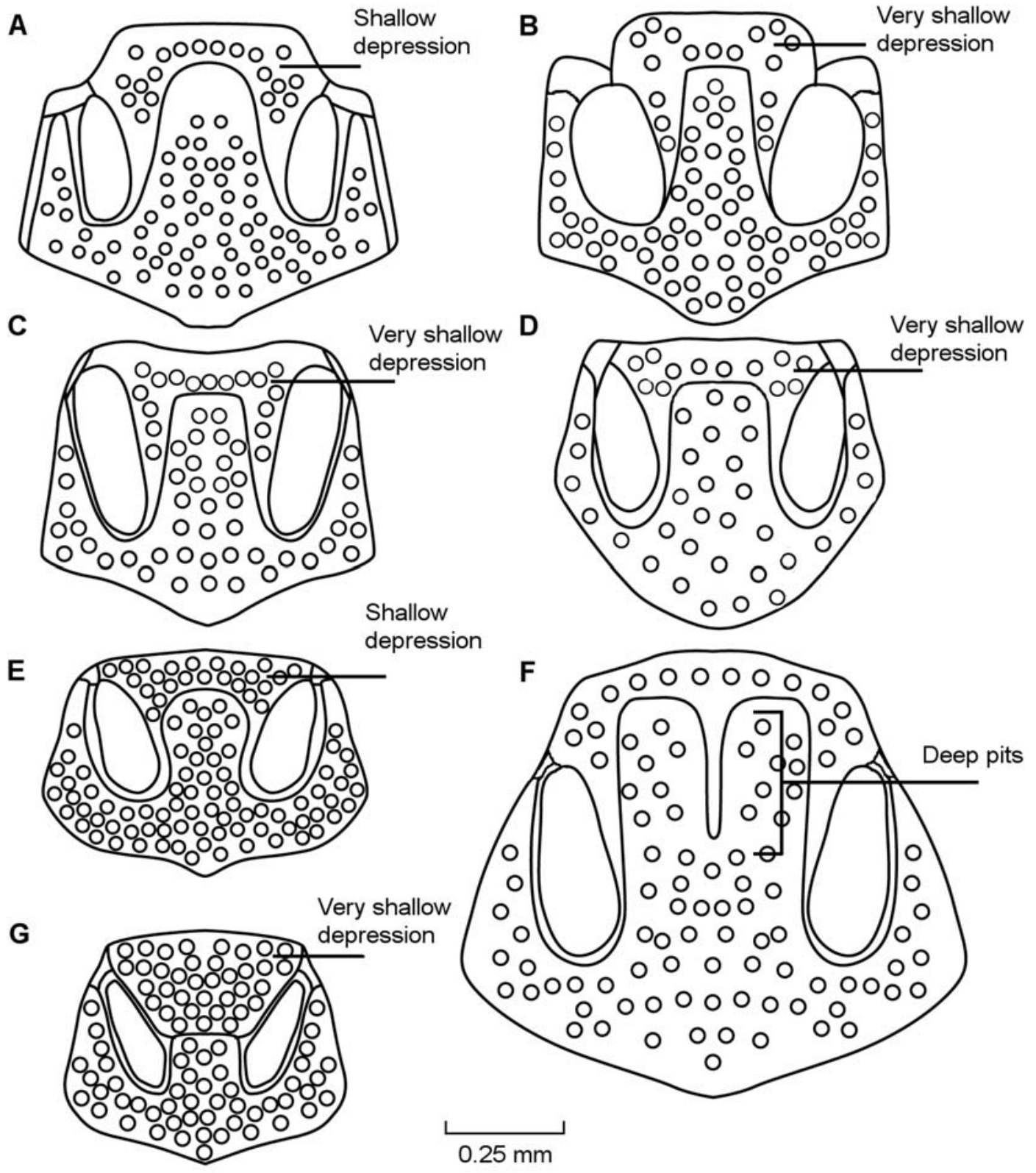

Fig. 12. Line diagrams showing differences in sternal structure between the new genera and species of small forestendemic relict taxa and those similar ones described by Scholtz \& Howden (1987a): A, Aliuscanthoniola similaris, B, Parvuhowdenius harrisoni, C, Nebulasilvius insularis, D, N. johani, E, Peckolus poenskopius, F, Endroedyolus paradoxus, G, Outenikwanus tomentosus.

P. alpinus Howden \& Scholtz also has some short recurved setae on the elytra while $P$. poenskopius sp. n. has minute recurved setae.

Material examined. Holotype: ơ S.Afr; Tvl. Nelshoogte, Knuckles rocks for 25.47 S-30.50 E,
12.2.1987; E-Y:2448, moder. wet for litt., Leg. Endrödy-Younga. (TMSA). Paratypes: 5ㅇ, same data. (3 TMSA, 2 UPSA).

Remarks. This forest is classified in the Mpumalanga mistbelt forest type. Its elevation is between 


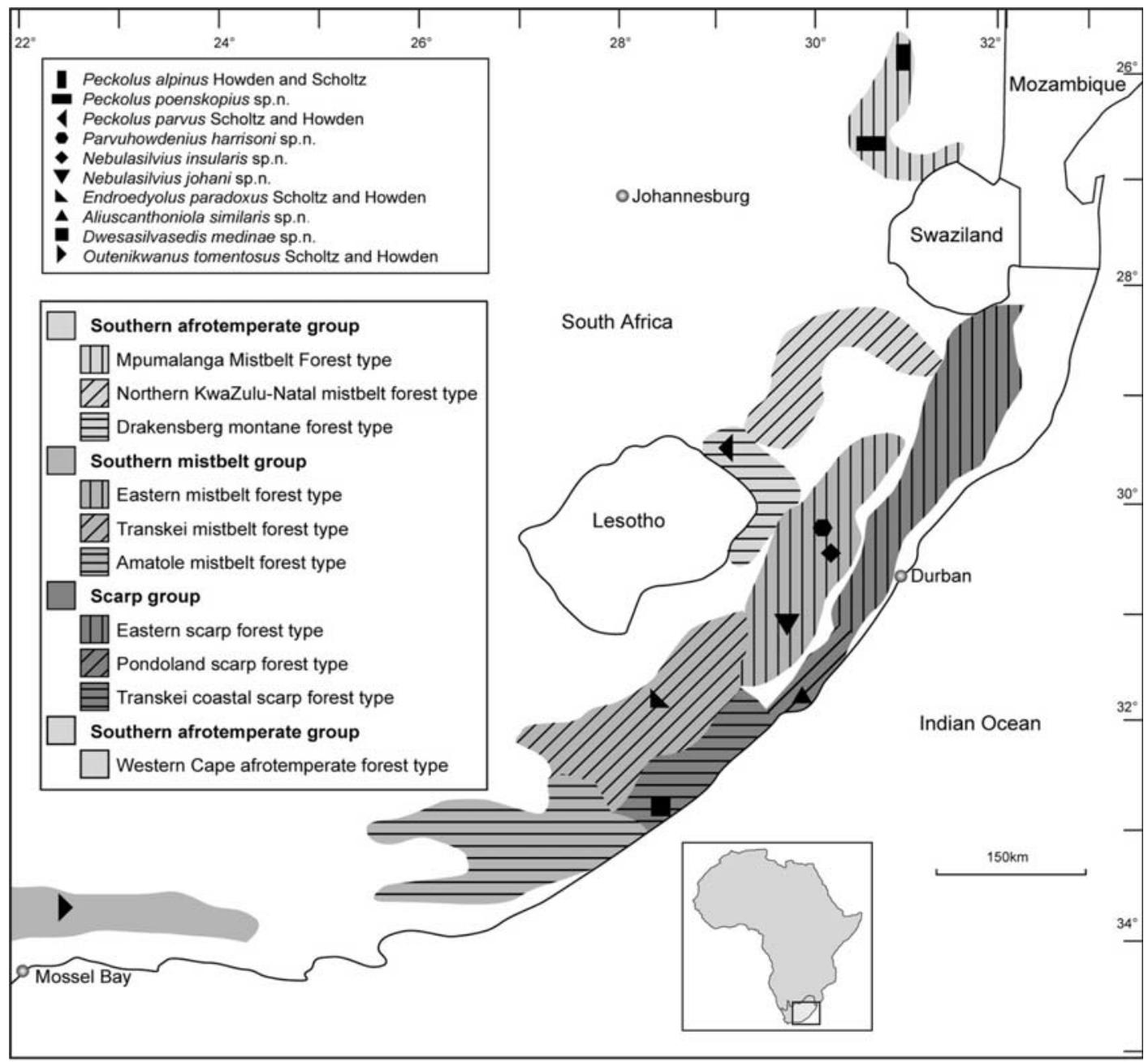

Fig. 13. Map showing the distribution of all the new species described in this study with all the other southern African species of small, forest-endemic relict canthonines in relation to the different forest types.

$1200 \mathrm{~m}$ and $1500 \mathrm{~m}$ and it receives about $1142 \mathrm{~mm}$ of rain during summer. The average yearly temperature is $17.4^{\circ} \mathrm{C}$.

Etymology. Poenskop is an old Afrikaans word for a person with a very short and bristly haircut.

\section{Distribution of the new genera and species}

Von Maltitz (2003) divided the South African forests into seven main groups. These groups were again subdivided into different types of forests.

Dwesasilvasedis medinae and Aliuscanthoniola similaris were recorded from the scarp group (Transkei coastal scarp and Pondoland coastal scarp forest type, respectively). All the species of Parvuhowdenius, Nebulasilvius and Endroedyolus paradoxus Scholtz \& Howden have been recorded from the southern mistbelt group; the species in Nebulasilvius and Parvuhowdenius are from eastern mistbelt forest type in this group while Endroedyolus paradoxus is from the Transkei mistbelt forest type. Although Parvuhowdenius and Nebulasilvius are from the same type of forest, Karkloof forest (type locality for Parvuhowdenius) is situated at higher altitude than the forests inhabited by the species of Nebulasilvius. Peckolus alpinus and P. poenskopius are both found in the Mpumalanga mistbelt forest type which is in the northern mistbelt group. Peckolus parvus falls in the northern afrotemperate 
group, while Outenikwanus tomentosus Scholtz \& Howden falls in the southern afrotemperate group.

\section{ACKNOWLEDGEMENTS}

We thank J. Harrison and R. Muller of the Transvaal Museum, Pretoria, South Africa, for the loan of specimens.

\section{REFERENCES}

COWLING, R.M. 1983. Phytochorology and vegetation history in the south-eastern Cape, South Africa. Journal of Biogeography 10: 393-419.

DAVIS, A.L.V., SCHOLTZ, C.H. \& HARRISON, J. du G. 1999. New and threatened Afrotropical, dung beetle taxa in the Gondwanaland tribe Canthonini (Coleoptera: Scarabaeidae). African Entomology 7(1): 77-84.

EELEY, H.A.C., LAWES, M.J. \& PIPER, S.E. 1999. The influence of climate change on the distribution of indigenous forest in KwaZulu-Natal, South Africa. Journal of Biogeography 26, 595-617.

DESCHODT, C.M., KRYGER, U. \& SCHOLTZ, C.H. (2007). New taxa of relictual Canthonini dung beetles (Scarabaeidae: Scarabaeinae) utilizing rock hyrax middens as refuges in South-western Africa Insect Systematics and Evolution 38(4): 361-367.

FROLOV, A.V. \& SCHOLTZ, C.H. 2003. A new genus and species of dung beetle from Southern Namibia (Coleoptera: Scarabaeinae). African Entomology 11(2): 297-299.

FROLOV, A.V. 2005. A new species of the dung beetle genus Namakwanus (Coleoptera, Scarabaeidae) from Namibia. In: Konstantinov, A., Tishechkin, A. \& Penev, L. (Eds) Contributions to Systematics and Biology of Beetles, Papers Celebrating the 80th Birthday of Igor Konstantinovich Lopatin. 245-247. Pensoft Publishers Sofia, Moscow.

GRISWOLD, C.E. 1991. Cladistic biogeography of Afromontane spiders. Australian Systematic Botany 41(1): 73-89.

HAFFER, J. 1969. Speciation in Amazon forest birds. Science 165: 131-137.

HOWDEN, H.F. \& SCHOLTZ, C.H. 1987. A revision of the African genus Odontoloma Boheman (Coleoptera: Scarabaeidae: Scarabaeinae). Journal of the Entomological Society of Southern Africa 50: 155-192.

HOWDEN, H.F. \& SCHOLTZ, C.H. 1988. A second species of the African genus Peckolus Scholtz and Howden (Scarabaeidae: Scarabaeini). Journal of the Entomological Society of Southern Africa 51: 133-136.

JOSSO, J.F. \& PRÉVOST, P. 2001. Contribution à la connaissance des Scarabaeidae africains I. (Coleo- ptera, Scarabaeidae, Coprinae). Cahiers Magellanes Hors-Serie 2: 1-14.

LAWRENCE, R.F. 1953. The Biology of the Cryptic Fauna of Forests, with Special Reference to the Indigenous Forests of South Africa. A.A. Balkema, Cape Town and Amsterdam.

LOW, A.R. \& REBELO, A.T.G. (Eds) 1996. Vegetation of South Africa, Lesotho and Swaziland. A companion to the vegetation map of South Africa, Lesotho and Swaziland. Department of Environmental Affairs and Tourism, Pretoria.

MARTIN, A.R.H., 1968. Pollen analysis of Groenvlei Lake sediments Knysna (South Africa). Review of Palaeobotany and Palynology 7: 107-144.

MEADOWS, M.E. \& LINDER, H.P. 1993. A palaeoecological perspective on the origin of Afromontane grasslands. Journal of Biogeography 20: 345-355.

MEDINA, C. \& SCHOLTZ, C. H. 2005. Systematics of the southern African genus Epirinus Reiche (Coleoptera: Scarabaeinae: Canthonini): descriptions of new species and phylogeny. Insect Systematics and Evolution 36(2): 145-160.

MUCINA, L. \& RUTHERFORD, M.C. (Eds) 2006. The Vegetation of South Africa, Lesotho and Swaziland. Strelitzia 19. South African National Biodiversity Institute, Pretoria.

PHILIPS, T.K., PRETORIUS, E. \& SCHOLTZ, C.H. 2004. A phylogenetic analysis of dung beetles (Scarabaeidae: Scarabaeinae): unrolling an evolutionary history. Invertebrate Systematics 18: 53-88.

RUTHERFORD, M.C. \& WESTFALL, R.H. 1994. Biomes of southern Africa: an objective categorization. Memoirs of the Botanical Survey of South Africa 63: 1-94.

SCHOLTZ, C.H. \& HOWDEN, H.F. 1987a. A revision of the southern African Canthonina (Coleoptera: Scarabaeidae: Scarabaeinae). Journal of the Entomological Society of Southern Africa 50: 75-119.

SCHOLTZ, C.H. \& HOWDEN, H.F. 1987b. A revision of southern African genus Epirinus Reiche (Coleoptera: Scarabaeidae: Scarabaeinae). Journal of the Entomological Society of Southern Africa 50: 121-154.

STUCKENBERG, B.R. 1962. The distribution of the montane palaeogenic element in the South African invertebrate fauna. Annals of the Cape Provincial Museums 2: 190-205.

VAN DER MERWE, Y. \& SCHOLTZ, C.H. 2005. New species of flightless Trogidae from South African relict forest fragments. African Entomology 13(1): 181186.

VON MALTITZ, G., MUCINA, L., GELDENHUYS, C., LAWES, M., EELEY, H. \& ADIE, H. 2003. Classification system for South African indigenous forests: An objective classification for the Department of Water Affairs and Forestry. Environmentek Report, ENV-P-C 2003-017. CSIR, Pretoria. 